\title{
DOES BREASTFEEDING OR NOT AFFECT A BETTER MATERNAL QUALITY OF LIFE? : LITERATURE REVIEW
}

\author{
Aulia Rahma Oktaviya ${ }^{1^{*}}$, Gatut Hardianto ${ }^{2}$, Budi Utomo ${ }^{3}$, Ivon Diah Wittiarika ${ }^{4}$ \\ ${ }^{1}$ Bachelor program of Midwifery, Faculty of Medicine, Universitas Airlangga, Surabaya, 60131, Indonesia \\ ${ }^{2}$ Consultant in Departement of Obstetric and Gynecologic Universitas Airlangga, Soetomo Hospital, Surabaya, Indonesia \\ ${ }^{3}$ Lecturer in Departement of Public Health \& Preventive Medicine, Faculty of Medicine, Universitas Airlangga, Surabaya, Indonesia \\ ${ }^{4}$ Lecturer in Midwifery Program, Faculty of Medicine, Universitas Airlangga, Surabaya, Indonesia
}

\section{INFORMASI ARTIKEL:}

\section{Riwayat Artikel:}

Tanggal diterima: September 2020

Tanggal di revisi: September 2020

Tanggal di Publikasi: Oktober 2020

Key Word : Breastfeeding,

Duration of Breastfeeding,

Maternal Quality of Life,

Literature Review

\begin{abstract}
A B S T R A C T
Quality of life is important to achieve the best performance of mothers. Maternal quality of life is usually measured by WHOQOL-BREF standards (quality of life of the World Health Organization-BREF), SF-36 (Short-36), or MGI (Mother Generated Index). One factor that affects the maternal quality of life is breastfeeding. The practice of breastfeeding is the mother who is breastfeeding (giving only breast milk) and the mother who is not breastfeeding (with formula milk) as well as seeing the length of breastfeeding time for less than 6 months or more than 6 months. This literature review has research question with PICO standard to get the aim about the correlation between the practice of breastfeeding and maternal quality of life. 466 literatures were obtained from the SCOPUS, Proquest, Google Scholar, PubMed and EBSCOhost databases. Literature screening is done by looking at the inclusion and exclusion criteria that have been set so that 10 literatures will be reviewed. Most of the literature reports that mothers who breastfeed and continue to breastfeed even though only a month has a better quality of life than mothers who did not breastfeed. One study said that breastfeeding causes a decrease in the maternal quality of life, as well as several other studies that found no significant correlation between breastfeeding practices and maternal quality of life. This result can be used as a reference for the health policy to promote breastfeeding and quality of life.
\end{abstract}

\section{INTRODUCTION}

Quality of Life (QoL) is a multidimensional and dynamic concept that affects an individual's physical, psychological, social and spiritual performance in aspects of life (Rezaei et al., 2016). Mothers in achieving quality of life are influenced by many factors such as sociodemographic factors, cultural factors, health factors, and others (Zubaran and Foresti, 2011; Triviño-Juárez et al., 2016). Sari (2019) mentions that there are 2 factors that affect quality of life namely internal factors and external factors. One of the external factors that affect the quality of life of postpartum mothers is mother's choices for breastfeed her child.

The World Health Organization (2018) recommends breastfeeding for newborn from the first hour of birth commonly called early breastfeeding initiation and the baby should get exclusive breastfeeding at least in the first 6 months. Breastfeeding is a very important aspect in optimizing the health and well-being of infants because it provides both short-term and long-term benefits for mothers, children, families, and society (Victoria, C. G., et al., 2016). Breastfeeding can be categorized into three pattern categories namely exclusive breastfeeding, predominant breastfeeding and partial breastfeeding (Kemenkes RI., 2014). Breastfeeding is also categorized based on the length of breastfeeding such as 2-4 months, up to 6 months, and more than 6 months (Islami, 2016).

*Korespondensi: auliaoktaviyar@gmail.com 
Riskesdas Indonesia (2018) reports $58.2 \%$ of mothers who have IMD and $41 \%$ who continue breastfeeding (with breast milk) for less than 6 months. The implementation of breastfeeding practices that are not same between each person make a questions about whether this will affect the quality of life of the mother or not. Midwives as first-line health workers need to provide counseling on the importance of breastfeeding and maintaining quality of life. This is also in accordance with Permenkes No. 1464 / Menkes / Per / X / 2010 in which midwives have the authority to provide midwifery services for maternal and infant health.

This research was conducted with the aim to determine the correlation of breastfeeding practice with maternal quality of life based on the study of several literary representations. Hopefully, this research will be useful for scientific information in developing midwifery knowledge especially in terms of breastfeeding practices and quality of life for mothers.

\section{METHOD}

A review of the literature was undertaken to locate relevant studies in the areas of breastfeeding, and QoL. The research question with PICO standard namely "What is the correlation between breastfeeding practices and maternal quality of life?". The databases searched included Proquest, EBSCOhost, Pubmed, Google Scholar, and Scopus. The literature taken in this study was all research that illustrates the correlation between breastfeeding practices and outcomes in the form of quality of life for mothers, literature in English and Indonesian, and full text and open access literature. Non-research studies, interventional, qualitative, and systematic review studies were excluded. Mothers who had chronic diseases during breastfeeding were also excluded from this study.
The determination of literature is reported in the PRISMA flowchart. The screened literatures will be assessed for quality using the Quality Assessment Tool for Quantitative Studies from the Effective Public Health Practice Project (EPHPP). After that, the literatures will be extracted for the synthesis of relevant themes

\section{RESULT AND DISCUSSION}

\section{Overview of the studies}

10 literatures were obtained from 466 literatures screening process (Figure 1). Total participants involved in these studies were 6,884 participants spread from Asia, Europe and America. Summary details of the studies are presented in Table 1.

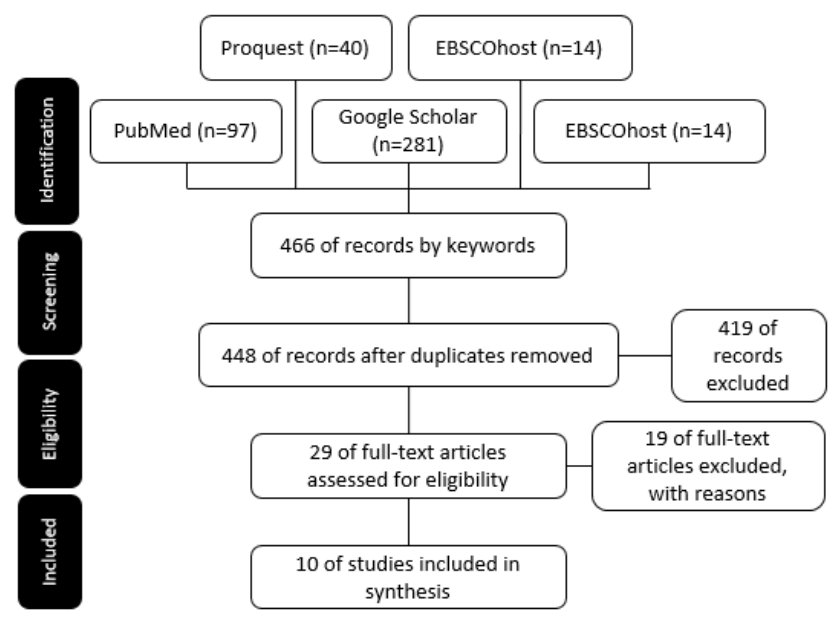

Figure 1. PRISMA flowchart of screening process

\section{Sociodemographic characteristic}

The results from 10 literatures obtained several sociodemographic overview: age, education, economic conditions and method of delivery. The average age of participants in this study ranged from 15 to 32 years. The age factor was inversely correlation with QoL (Islami, 2016; Kamalifard, et al., 2018; Rezaei et al., 2016; Zubaran \& Foresti, 2011). The inverse correlation of QoL with age because of 
reduced physical ability of the mother to breastfeed her child and reducing QoL (Kamalifard et al., 2018). This statement was also supported by Rezaei et al. (2016) that age of mothers under 30 years is better in QoL compared with more than 30 years. Maternal ages between 20-29 years tend to have better prolactin levels for best lactation (Sawin, et al., 1989).

Mothers with a high level of education were one of the factors in the high QoL scores of mothers in labor (Martínez-Galiano, et al., 2019; Rezaei et al., 2016; Zubaran \& Foresti, 2011). It happened because a person with higher education was able to control their emotions and social life (Islami, 2016). But Chen et al. (2007) and Mortazavi et al. (2014) found that higher education levels had nothing to do with perceptions of health and mental health. It might be due to procedural bias in collected data. 

The Southeast Asian Journal of Midwifery Vol. 6, No.2, Oktober 2020, p: 68-75

Table 1

Summary of the literatures

\begin{tabular}{|c|c|c|c|c|c|}
\hline $\begin{array}{l}\text { Author and year } \\
\text { of publication }\end{array}$ & Source and Country & Instrument & Method and sample size & Key findings & $\begin{array}{l}\text { Rate of } \\
\text { Quality }\end{array}$ \\
\hline $\begin{array}{l}\text { Triviño-Juárez et } \\
\text { al., } 2016\end{array}$ & $\begin{array}{l}\text { Scopus, midwifery, 2016, 34, } \\
\text { 230-238, Spain }\end{array}$ & SF-36 & $\begin{array}{l}\text { Case Control, } 364 \text { women who gave } \\
\text { birth at a public hospital at Madrid }\end{array}$ & $\begin{array}{l}\text { There was no significant correlation between maternal quality of } \\
\text { life in the six weeks postpartum both for mothers who breastfeed } \\
\text { and mothers who did not breastfeed }\end{array}$ & Strong \\
\hline $\begin{array}{l}\text { Mortazavi et al., } \\
2014\end{array}$ & $\begin{array}{l}\text { Pubmed, Iran J Pediatri, 2014, } \\
\text { 2014, 156049, Iran }\end{array}$ & $\begin{array}{l}\text { WHOQOL- } \\
\text { BREF }\end{array}$ & $\begin{array}{l}\text { Cohort study, } 547 \text { eligible } \\
\text { breastfeeding mothers with infants, } \\
\text { aged between } 2 \text { and } 6 \text { months }\end{array}$ & $\begin{array}{l}\text { Mothers who decided to continue exclusive breastfeeding at } 2 \text { and } \\
4 \text { months postpartum had significantly better quality of life than } \\
\text { those who did not continue breastfeeding. }\end{array}$ & Strong \\
\hline Chen et al., 2007 & $\begin{array}{l}\text { Pubmed, Quality of Life } \\
\text { Research, 2007, 16, 1281-1288, } \\
\text { Taiwan }\end{array}$ & SF-36 & Cohort study, 1.747 mothers & $\begin{array}{l}\text { Mothers who did not breastfeed their children (giving formula } \\
\text { milk) had lower scores than mothers who breastfed their children } \\
\text { even though less than } 1 \text { month }\end{array}$ & Strong \\
\hline $\begin{array}{l}\text { Kamalifard et al., } \\
2018\end{array}$ & $\begin{array}{l}\text { Scopus, IJWHR, 2018, 6, 84-89, } \\
\text { Iran }\end{array}$ & WHO-QoL & $\begin{array}{l}\text { Descriptive Cross sectional, } 380 \\
\text { women in } 10 \text { urban health centers in } \\
\text { Ilam province in west of Iran. }\end{array}$ & $\begin{array}{l}\text { QoL with breastfeeding is positively correlated with each other } \\
\text { and getting better with family and community support. }\end{array}$ & Moderate \\
\hline $\begin{array}{l}\text { Aminova et al., } \\
2018\end{array}$ & $\begin{array}{l}\text { Scopus, Voprosy Detskoi } \\
\text { Dietologii, 2018, 16, 13-19, } \\
\text { Rusia }\end{array}$ & SF-36 & $\begin{array}{l}\text { Cross sectional, } 151 \text { mothers who have } \\
\text { baby }\end{array}$ & $\begin{array}{l}\text { Mothers who breastfeed significantly improve the parameters of } \\
\text { quality of life (physical function and role function) compared to } \\
\text { mothers who didn't breastfeed. }\end{array}$ & Moderate \\
\hline $\begin{array}{l}\text { Zubaran et al., } \\
2011\end{array}$ & $\begin{array}{l}\text { Pubmed, Breastfeed Med, 2011, } \\
\text { 6, 25-30, Brazil }\end{array}$ & WHO-QoL & $\begin{array}{l}\text { Correlation, } 89 \text { mothers from southern } \\
\text { Brazil }\end{array}$ & $\begin{array}{l}\text { There was a significant correlation between mothers who } \\
\text { breastfeed exclusively with the quality of life of mothers } \\
\text { compared to partial breastfeeding. }\end{array}$ & Moderate \\
\hline $\begin{array}{l}\text { Rezaei et al., } \\
2016\end{array}$ & $\begin{array}{l}\text { Scopus, scientifica, 2016, 2016, } \\
\text { Iran }\end{array}$ & SF-36 & $\begin{array}{l}\text { Cross sectional, } 380 \text { mothers in west } \\
\text { Iran }\end{array}$ & $\begin{array}{l}\text { No significant correlation was found between breastfeeding and } \\
\text { not breastfeeding with the quality of life of the mother. }\end{array}$ & Moderate \\
\hline Islami, 2016 & $\begin{array}{l}\text { Google Scholar, UMS, 2016, } \\
\text { Indonesia }\end{array}$ & SF-36 & $\begin{array}{l}\text { Observasional Cross sectional, } 140 \\
\text { mothers who breastfeed their baby }\end{array}$ & $\begin{array}{l}\text { Mothers who breastfeed longer (for } 6 \text { months) have a direct } \\
\text { correlation with the maternal quality of life. }\end{array}$ & Moderate \\
\hline $\begin{array}{l}\text { Martínez- } \\
\text { Galiano et al., } \\
2019\end{array}$ & $\begin{array}{l}\text { Pubmed, Journal of Clinical } \\
\text { Medicine, 2019, 8, 324, Spain }\end{array}$ & SF-36 & $\begin{array}{l}\text { Cross sectional, } 2990 \text { spanish puerperal } \\
\text { women }\end{array}$ & $\begin{array}{l}\text { Women who did not breastfeed did not experience worse quality } \\
\text { of life scores than those who breastfeed. }\end{array}$ & Moderate \\
\hline $\begin{array}{l}\text { Grylka-Baeschlin } \\
\text { et al., } 2014\end{array}$ & $\begin{array}{l}\text { Proquest, BMC Pregnancy\& } \\
\text { Childbirth, 2014, 14, 1-13, } \\
\text { German \& Swiss }\end{array}$ & MGI & $\begin{array}{l}\text { Two-stage survey, } 129 \text { women in two } \\
\text { rural hospital } 10 \mathrm{~km} \text { apart, on opposite } \\
\text { sides of the German-Swiss border }\end{array}$ & $\begin{array}{l}\text { Mothers who uninformed and unsupported while in the hospital, } \\
\text { provide exclusive breastfeeding, and have adequate support for } \\
\text { breastfeeding show a decrease in the quality of life of the mother } \\
\text { in the puerperium. }\end{array}$ & Moderate \\
\hline
\end{tabular}


with interview that could inadvertently influence mother's understanding of the question (Chen et al., 2007).

Economic status was directly related to the QoL because it provides welfare, easy access to health, and care to continue breastfeeding (Triviño-Juárez et al., 2016; Kamalifard et al., 2018). It contradicted with Aminova's research (2018) that the more prosperous the material will reduce the compliance of mothers to breastfeed their children, even though mothers who breastfeed were positively correlated with the QoL. In line with Aminova, Islami (2016) found that mothers with higher incomes tended to be busy so that reducing their time to socialize, reducing general health, and reducing mental health due to fatigue.

The delivery method was divided into vaginal birth and caesarean sections. There was no significant correlation between the delivery method and the quality of life of the mother (Grylka-Baeschlin, et al., 2014; Rezaei et al., 2016). It was due to differences concept in QoL instrument (Grylka-Baeschlin, van Teijlingen and Gross, 2014). Unlike MartinezGalino (2019) which stated that having caesarean section was a factor in the decrease of QoL in the puerperium. That is due to the delivery of a section with surgery that could cause pain, discomfort, and other health symptoms so that their physical health is worse than mothers who give birth normally (Mousavi S.A., et al., 2013).

\section{Breastfeeding or not breastfeeding with M-QoL}

The analysis of correlation between breastfeeding practices and quality of life for mothers was obtained from nine literatures that were reviewed by researchers. Six literatures stated that breastfeeding practices are significantly related to the maternal quality of life (Aminova, et al., 2018; Chen et al.,
2007; Grylka-Baeschlin et al., 2014; Kamalifard et al., 2018; Mortazavi, Mousavi, \& Chaman, 2014; Zubaran \& Foresti, 2011), while three other literatures stated that breastfeeding practices have no significant correlation to the maternal; quality of life (Rezaei et al., 2016; Triviño-Juárez et al., 2016; Martínez-Galiano et al., 2019).

The practice of breastfeeding is significantly related to the quality of life influenced by maternal sociodemographic factors, husband / family support, physical, mental, social, environmental, and appropriate counseling / support from the service provider (mother and child center). One study found that someone who lacked the support from her husband and family was prone to mental disorders which is one of the dimensions of quality of life (Webster et al., 2011). Other studies mention the difficulties of breastfeeding such as sore nipple, nipple confusion, and maternal perceptions of lack of breast milk are factors that decrease maternal quality of life (Rahmatnejad and Bastani, 2011; Lau et al., 2017). This can have an impact on the physical and mental condition of the mother.

One quite different study was breastfeeding and getting support for breastfeeding causes a decrease in the quality of life of the mother (Grylka-Baeschlin, van Teijlingen and Gross, 2014). The experience of breastfeeding mothers both in the past and at present will affect the perception of mothers about breastfeeding. Watskin's research (2011) found that poor breastfeeding experiences such as nipple sores or mastitis will increase maternal stress thereby reducing the psychological dimension. Another factor that causes a decrease in quality of life was because the routine postpartum care that did not chosen by mother can't improve the condition of the mother (Shaw et al., 2006). Therefore, WHO (2010) recommends that the delivery of health 


\section{The Southeast Asian Journal of Midwifery Vol. 6, No.2, Oktober 2020, p: 68-75

services should be focused on both mother and baby needs. The results of research that show differences compared to other studies need further attention to its accuracy because the measuring tool used to measure variables and quality of life scores of mothers namely MGI scores shows a rather low correlation compared to other instruments (Symon, et al., 2015).

The results of three other studies which state that there was no significant correlation between breastfeeding practices and QoL found that breastfeeding is not a factor that directly affects the quality of life of mothers but QoL was affected with other factors such as the type of labor, prematurity or problems in labor that actually have an impact on quality living mother (Martínez-Galiano et al., 2019). The research of Martinez-Galiano (2019) applied a data collection procedure with a selfcompleted questionnaire through an online questionnaire and participants could ask by telephone if they had difficulties. This can be a procedural bias because not all respondents have the ability and experience of working with computers so that it may cause misunderstanding, cognitive limitations, and others (Bethlehem, 2010). Non-probability convenience sampling might lead to sampling bias in interpreting the result (Riffenburgh, 2012). Furthermore, confounding bias could be happened in Rezaei's research because of respondent's education levels $<12$ years more than> 12 years and as a majority of mothers not working or housewives (Skelly, 2012).

\section{Duration of breastfeeding with M-QoL}

The analysis of correlation between breastfeeding duration and maternal quality of life was obtained from 4 reviewed literature. The duration of breastfeeding discussed was mothers who continued breastfeeding $<6$ months, continued breastfeeding $>6$ months, and also compared with mothers who did not breastfeeding.

Mortazavi et al. (2014) stated that mothers who continued breastfeeding in the second and fourth months postpartum had better quality of life (physical dimensions and mental health) compared to mothers who did not continue breastfeeding at all. It was due to the second month after childbirth becomes the return period of psychological conditions and mood changes that are uncertain from pregnancy to normal conditions again (Mortazavi, Mousavi and Chaman, 2014). Chen (2007) found in his study that mothers who breastfed $>6$ months had a higher quality of life score than mothers who breastfed $<6$ months or did not breastfeed at all. It was shown significantly in physical function, general health, and mental health. It was most likely due to the lower stress not only because of the benefits of lactation but also a sense of satisfaction because it has become a good bond between mother and child (Chen et al., 2007; Flacking, et al., 2006). These opinions are further strengthened by Islami (2016) to obtain an increase in the value of quality of life as much as 2,975 times every additional month.

One literature examines between breastfeeding and those who did not breastfeeding starting from the sixth week to the sixth month postpartum and found no significant correlation to all dimensions of maternal quality of life (Triviño-Juárez et al., 2016). It could be due to several factors; the technic of sampling that is difficult to generalize, only focusing on primigravida mothers with healthy babies so that there was no comparison of multigravida mothers, there was a possibility that the mother's mental condition is good before childbearing, mother's sleep patterns and flowing breast milk wasn't asked in breastfeeding practices 


\section{CONCLUSION}

Most mothers who choose to breastfeed their children have a better quality of life than mothers who did not breastfeed their children. Breastfeeding helps mothers achieve good physical, mental, social and environmental conditions and improve the maternal quality of life scores. There were studies that say that breastfeeding or not breastfeeding does not affect the quality of life of mothers directly, but it have a few lack. Longer duration of breastfeeding gives a better effect on the maternal quality of life than less duration of breastfeeding because of the benefit from lactation.

Midwives need to pay attention to the needs of mothers in providing health services to improve the maternal quality of life. This result can be used as a reference for the health policy to promote breastfeeding and quality of life.

\section{REFERENCE}

Aminova, A. I., Gumbatova, Z. F., Pestova, A. S., Lakhova, S. A., Abdullayeva, G. D. (2018) 'Quality of life of mothers and commonwealth to breastfeeding', Voprosy Detskoi Dietologii, 16, pp. 13-19.

Bethlehem, J. (2010) 'Selection bias in web surveys', International Statistical Review, 78(2), pp. 161-188. doi: 10.1111/j.17515823.2010.00112.x.

Chen, Y. C. et al. (2007) 'The association between infant feeding pattern and mother's quality of life in Taiwan', Quality of Life Research, 16(8), pp. 1281-1288. doi: 10.1007/s11136-007-9233-1.

Flacking, R., Ewald, U., \& Nyqvist, K. H. et al. (2006) 'Trustful bonds: a key to "'becoming a mother" "and to reciprocal breastfeeding. Stories of mothers of very preterm infants at a neonatal unit.', Social Science \& Medicine, 62, pp. 70-80.
Grylka-Baeschlin, S., van Teijlingen, E. and Gross, M. M. (2014) 'Cultural differences in postnatal quality of life among Germanspeaking women - a prospective survey in two countries', BMC Pregnancy and Childbirth, 14(1), pp. 1-13. doi: 10.1186/1471-2393-14277.

Islami (2016) 'Korelasi Lama Menyusui dan Status Sosial Ekonomi dengan Kualitas Hidup Ibu', Universitas Muhammadiyah Surakarta.

Kamalifard, M. et al. (2018) 'Quality of life predictors in breastfeeding mothers referred to health centers in Iran', International Journal of Women's Health and Reproduction Sciences, 6(1), pp. 84-89. doi: 10.15296/ijwhr.2018.15.

Kemenkes RI. Pusat Data dan Informasi Situasi dan Analisis ASI Eksklusif (2014) 'Kementrian Kesehatan Replubik Indonesia'.

Lau, Y. et al. (2017) 'Breastfeeding attitude, health-related quality of life and maternal obesity among multi-ethnic pregnant women: A multi-group structural equation approach', International Journal of Nursing Studies. Elsevier Ltd, 67, pp. 71-82. doi: 10.1016/j.ijnurstu.2016.12.004.

Martínez-Galiano, J. et al. (2019) 'Quality of Life of Women after Giving Birth: Associated Factors Related with the Birth Process', Journal of Clinical Medicine, 8(3), p. 324. doi: 10.3390/jcm8030324.

Mortazavi, F., Mousavi, S. A. and Chaman, R. (2014) 'Do Maternal Quality of Life and Breastfeeding Difficulties Influence the Continuation of Exclusive Breastfeeding?', Iran J Pediatri, 2014(156049).

Mousavi S.A., Mortazavi F., Chaman R., K. A. (2013) 'Quality of life after cesarean and vaginal delivery', Oman Med Journal, 28, pp. 245-251.

Rahmatnejad, L. and Bastani, F. (2011) 'Reasons of exclusive breasfeeding discontinuation among primiparas', Iran Journal of Nursing, 24, pp. 42-53. 
Rezaei, N. et al. (2016) 'Maternal HealthRelated Quality of Life and Its Predicting Factors in the Postpartum Period in Iran', Scientifica, 2016. doi: 10.1155/2016/8542147.

Riffenburgh, R. H. (2012) 'Chapter 1 Planning Studies: From Design to Publication', in Riffenburgh, R. H. B. T.-S. in M. (Third E. (ed.). San Diego: Academic Press, pp. 1-26. doi: https://doi.org/10.1016/B978-0-12-3848642.00001-9.

Sawin, C. T. et al. (1989) 'Serum Prolactin and Aging: Basal Values and Changes With Estrogen Use and Hypothyroidism', Journal of Gerontology, 44(4), pp. M131-M135. doi: 10.1093/geronj/44.4.M131.

Shaw, E. et al. (2006) 'Systematic review of the literature on postpartum care: Effectiveness of postpartum support to improve maternal parenting, mental health, quality of life, and physical health', Birth, 33(3), pp. 210-220. doi: 10.1111/j.1523536X.2006.00106.x.

Skelly AC, Dettori JR, and Brodt ED. Assessing bias: the importance of considering confounding. Evid Based Spine Care J. 2012;3(1):9-12. doi:10.1055/s-0031-1298595

Symon, A. et al. (2015) 'The feasibility and acceptability of using the Mother-Generated Index (MGI) as a Patient Reported Outcome Measure in a randomised controlled trial of maternity care', BMC Medical Research Methodology. BMC Medical Research Methodology, 15(1), pp. 1-9. doi: 10.1186/s12874-015-0092-0.

Triviño-Juárez, J. M. et al. (2016) 'Quality of life of mothers at the sixth week and sixth month post partum and type of infant feeding', Midwifery. Elsevier, 34, pp. 230-238. doi: 10.1016/j.midw.2015.11.003.

Victoria, C. G., Bahl, R., Barros, A.J., Franca, G.V., Horton, S., Krasevec, J., Murch, S. and Sankar, M.J., Walker, N., Rollins, N. C. (2016) 'Breastfeeding in the 21 st century: epidemiology, mechanisms, and lifelong effect', Lancet Breastfeeding Series, 387 (10017, pp. 475-490. doi: http://dx.doi.org/10.1016/s0140-6736 (15)01024-7.

Webster, J. et al. (2011) 'Quality of life and depression following childbirth: Impact of social support', Midwifery. Elsevier, 27(5), pp. 745-749. doi: 10.1016/j.midw.2010.05.014.

Zubaran, C. and Foresti, K. (2011) 'The Correlation Between Breastfeeding and Maternal Quality of Life in Southern Brazil', 6(1). doi: 10.1089/bfm.2010.0017. 